\title{
IDENTIFIKASI LACTOBACILLUS GASSERI DARI ASI: KARAKTERISASI DAN PENGUJIAN BIOKIMIA
}

\author{
In-In Hanidah ${ }^{1}$, Dimas Erlangga ${ }^{2}$, Debby M. Sumanti ${ }^{1}$, Willa Kusumah Wardani ${ }^{3}$, \\ Serli Grachia ${ }^{3}$, dan Imas Siti Setiasih ${ }^{1}$. \\ ${ }^{1}$ Dosen Fakultas Teknologi Industri Pertanian, Universitas Padjadjaran \\ ${ }^{2}$ Dosen Fakultas Kedokteran, Universitas Padjadjaran \\ ${ }^{3}$ Mahasiswa Fakultas Teknologi Industri Pertanian, Universitas Padjadjaran \\ Jl. Raya Bandung - Sumedang Km.21, Jatinangor, Indonesia \\ Email: inin@unpad.ac.id; pinkyhanidah@yahoo.com
}

\begin{abstract}
ABSTRAK
ASI dari ibu yang sehat memiliki potensi yang besar mengandung bakteri probiotik spesies Lactobacillus. Hasil penelitian menunjukkan bahwa 20\% dari sampel lima ASI Ibu menyusui usia 12 - 60 hari setelah melahirkan mengandung bakteri probiotik Lactobacillus gasseri dengan karakteristik morfologi: gram positif, katalase negative, non motil, anaerob, bentuk koloni bulat dengan permukaan cembung, warna koloni putih susu agak krem, tekstur koloni agak keras, koloni tumbuh dibagian tengah media agar (anaerob), sel berbentuk basil dengan ukuran sel 2,0 $\mu \mathrm{m}$. sedangkan uji biokimia menunjukkan bahwa isolate L. glasseri terseleksi mampu menguraikan: DCellobiose, Saccharose, Maltotriose, Phosphatase, Leucine Arylamidase, Tryosine Arylamidase, Arbutin, Esculin hydrolysis, Ala-Phe-Pro_Arylamidase, $N$-Acetyl-D-Glucosamine, Phenylalanine Arylamidase, D-Glukose, 5-Bromo-4-chloro-3-indoxyl-beta-glucoside, L-Proline Arylamidase, DMannose, Arginine GP, D-Maltose.
\end{abstract}

Kata kunci: Lactobacillus gasseri, probiotik, ASI.

\begin{abstract}
Breast milk from healthy mothers has a great potential to contain the probiotic bacteria of the Lactobacillus species. The results showed that $20 \%$ of the five samples of breast milk, at days 12 to 60 after birth contained probiotic bacteria of Lactobacillus gasseri with morphology of bacterial: gram-positive, catalase- negative, non-motile, anaerob, rounded colony shape with convex surface, the color colony of slightly creamy, rather hard colony texture, anaerobic, basil-shaped cells with a cell size of $2.0 \mu \mathrm{m}$. Biochemical tests show that selected L. glasseri isolates are able to decipher: $D$ Cellobiose, Saccharose, Maltotriose, Phosphatase, Leucine Arylamidase, Tryosine Arylamidase, Arbutin, Esculin hydrolysis, Ala-Phe-Pro_Arylamidase, N-Acetyl-D-Glucosamine, Phenylalanine Arylamidase, D-Glukose, 5-Bromo-4-chloro-3-indoxyl-beta-glucoside, L-Proline Arylamidase, DMannose, Arginine GP, D-Maltose.
\end{abstract}

Keywords: Lactobacillus gasseri, probiotic, breast milk 


\section{PENDAHULUAN}

Probiotik merupakan kultur tunggal ataupun campuran bakteri hidup yang memiliki efek menguntungkan dengan meningkatkan keseimbangan bakteri dalam saluran pencernaan (Fuller, 1992 dalam Hartanti, 2005). Mikroflora yang umumnya digolongkan sebagai probiotik adalah yang memproduksi asam laktat seperti Lactobacillus dan Bifidobacteria (Roberfroid, 2000).

Secara umum, bakteri genus Streptococcus, Staphylococcus, Enterococcus, Lactobacillus, atau Enterobacteria merupakan bakteri anaerobic fakultatif dan Bifidobacterium merupakan bakteri pertama yang berkolonisasi di dalam usus bayi yang mengkonsumsi ASI (Marin et al., 2009)

L. gasseri dan L. acidophilus merupakan spesies utama dalam mikroflora manusia (Baltova\&Zhechko, 2014). L. gasseri merupakan bakteri gram positif, berbentuk batang, non spora, katalase negatif, dan bersifat anaerob (Falsen et al., 1999)

Bakteri probiotik pada ASI matur foremilk pada hari ke-10 mengandung bakteri probiotik sebanyak 5,3 x $10^{2} \mathrm{cfu} / \mathrm{ml}$ (Hanidah\&Elaz, 2015). Bakteri probiotik dapat ditemukan pada ASI sampai usia menyusui kurang dari 3 bulan (Portinson, 2013). Sampai saat ini, pemanfaatan strain probiotik (terutama Lactobacillus dan Bifidobacterium) direkomendasikan untuk menyeimbangkan mikroflora di dalam usus karena terbukti memberikan efek preventif dan terapeutik (Olivares et al., 2006).

Tujuan penelitian adalah untuk mengisolasi dan mengidentifikasi L. gasseri dari ASI dengan umur 12-24 hari setelah bayi lahir dengan metode pengujian Total Plate Count (TPC), mikroskopik, motilitas, katalase, dan biokimia menggunakan alat Vitek seri 2.0.

\section{METODE PENELITIAN}

Sampel ASI: sebanyak 5 wanita menyusui ekslusif dengan kriteria: (1) wanita dengan riwayat sehat sampai sampel diambil; (2) masa kehamilan normal; (3) tidak ada masalah saat melahirkan baik bayi maupun ibunya; (4) tidak mengalami mastitis pada payudara. Semua relawan telah menandatangani Surat Pernyataan Persetujuan untuk ikut serta dalam penelitian (Informed Consent) tanpa paksaan sesuai ketentuan dari Komisi Etik Penelitian Kesehatan yang dikeluarkan oleh Fakultas Kedokteran Universitas Padjadjaran.
Sampling: ASI yang diambil pada hari ke 12 - 90 setelah kelahiran. Kulit payudara dibersihkan dengan kain hangat steril, ASI dikumpulkan pada botol susu steril yang terhubung langsung dengan pompa ASI, selama perjalanan ke laboratorium di simpan pada cool storage suhu $4^{\circ} \mathrm{C}$ (Martin, et al., 2009).

Isolasi $L$. gasseri: sampel ASI diambil 1 $\mathrm{ml}$, dilakukan pengenceran sampai $10^{-3}$. Masing-masing pengenceran ditumbuhkan pada media MRS (Man Rogosa Sharpe, Oxoid), diinkubasi secara anaerobic dengan menggunakan anaerobic jar yang dilengkapi gas pack pada suhu $37^{\circ} \mathrm{C}$ selama 48 jam. Setiap koloni yang tumbuh dilakukan sub kultur ke dalam media MRS-broth diinkubasi pada suhu $37^{\circ} \mathrm{C}$ selama 24 jam. Masingmasing isolat dilakukan pemurnian dengan cara metode gores kuadran (Labeda, 1990).

Identifikasi L. gasseri: Isolat yang terpilih diamati morfologinya melalui pewarnaan gram dan pengamatan mikroskop. Isolat gram positif dilanjutkan pengujian katalase dan motilitas. Setiap isolat katalase negatif dan non motil dilanjutkan pengujian biokimia dengan menggunakan alat Vitek 2.0 Casrd type: ANC testing instrument 00001658F4A9 (12903).

\section{HASIL DAN PEMBAHASAN}

Hasil identifikasi morfologi dari 5 sumber sampel ASI wanita menyusui usia 12 90 hari diperoleh 27 isolat koloni dan yang terseleksi dengan ciri morfologi: gram positif, anaerob, katalase negatif, dan non motil terdapat 14 isolat (Tabel 1).

Setiap bakteri memiliki dinding sel yang berfungsi untuk memberi bentuk dan kekuatan terhadap sel, mengatur pertukaran zat-zat dari dan kedalam sel, dan terletak antara kapsul dan membrane sel. Bakteri gram positif hanya memiliki membrane sel dan lapisan peptidoglikan sehingga lebih sensitif terhadap penisilin dan penghambatan oleh pewarna basa lebih tinggi (Sukarminah, dkk., 2016)

Pengujian katalase dilakukan dengan pemberian larutan $\mathrm{H}_{2} \mathrm{O}_{2} 3 \%$ pada setiap isolat. Berdasarkan hasil pengujian katalase, 14 isolat murni yang terpilih menunjukkan hasil negative. Hal ini menunjukkan bahwa ke-27 isolat bakteri asam laktat (BAL) tersebut tidak memiliki flavoprotein yang dapat mereduksi $\mathrm{O}_{2}$ untuk menghasilkan hidrogen peroksida $\left(\mathrm{H}_{2} \mathrm{O}_{2}\right)$ atau superoksida $\left(\mathrm{O}^{2-}\right)$ dan tidak memiliki enzim 
katalase yang dapat menguraikan $\mathrm{H}_{2} \mathrm{O}_{2}$ menjadi $\mathrm{H}_{2} \mathrm{O}$ dan $\mathrm{O}_{2}$. Hidrogen peroksida terbentuk sewaktu metabolisme aerob, sehingga hanya mikroorganisme yang tumbuh dalam lingkungan aerob dapat menguraikan senyawa $\mathrm{H}_{2} \mathrm{O}_{2}$. Uji katalase positif ditandai dengan adanya reaksi antara $\mathrm{H}_{2} \mathrm{O}_{2}$ dengan enzim katalase seperti pada reaksi di bawah ini:

$2 \mathrm{O}_{2}+2 \mathrm{H}^{+} \rightarrow \mathrm{O}_{2}+\mathrm{H}_{2} \mathrm{O}_{2}$

$\mathrm{H}_{2} \mathrm{O}_{2} \rightarrow \mathrm{H}_{2} \mathrm{O}+1 / 2 \mathrm{O}_{2}$ (gelembung udara)

Tabel 1.

Hasil Uji Morfologi Sampel ASI

\begin{tabular}{llll}
\hline $\begin{array}{l}\text { KODE } \\
\text { ASI }\end{array}$ & $\begin{array}{l}\text { Jumlah } \\
\text { Koloni }\end{array}$ & $\begin{array}{l}\text { Jumlah Isolat } \\
\text { Gram Positif, } \\
\text { Katalase nega- } \\
\text { tive, Non motil }\end{array}$ & $\begin{array}{l}\text { Spesies } \\
\text { Lactobacillus }\end{array}$ \\
\hline $\mathrm{L}_{1}$ & 4 & 2 & L. glasseri \\
$\mathrm{L}_{2}$ & 3 & 1 & - \\
$\mathrm{L}_{3}$ & 9 & 4 & - \\
$\mathrm{L}_{4}$ & 4 & 1 & - \\
$\mathrm{L}_{5}$ & 7 & 6 & - \\
\hline
\end{tabular}

Bakteri memiliki berbagai aktivitas biokimia untuk pertumbuhan dan perbanyakan sel dengan menggunakan nutrisi yang diperoleh dari lingkungan sekitarnya. Transformasi biokimia dapat timbul didalam dan diluar dari bakteri yang diatur oleh katalis biologis yang dikenal sebagai enzim.

Setiap bakteri memiliki kemampuan dalam menggunakan enzim yang dimilikinya untuk degradasi karbohidrat, lemak, protein, dan asam amino. Isolat yang terpilih sebagai kandidat $L$. glasseri dilakukan uji lanjut biokimia dengan menggunakan alat Vitek seri 2.0. Hasil pengujian biokimia menunjukkan dari 14 isolat murni hanya 1 isolat yang teridentifikasi sebagai $L$. glasseri dengan hasil pengujian tersaji pada Tabel 2.

Hasil uji positif pada Tabel 2 sebagai indikator bahwa isolat kandidat $L$. glasseri mampu menguraikan senyawa tersebut. Pengamatan aktivitas biokimia atau metabolisme mikroorganisme bertujuan untuk mengetahui kemampuan bakteri menguraikan molekul yang kompleks maupun sederhana dari karbohidrat, lemak, protein dan asam nukleat.

Isolate L. glasseri terseleksi memiliki ciri morfologi: bentuk koloni bulat dengan permukaan cembung, warna koloni putih susu agak krem, tekstur koloni agak keras, koloni tumbuh dibagian tengah media agar (anaerob), sel berbentuk basil dengan ukuran sel 2,0 $\mu \mathrm{m}$.
Tabel 2

Hasil Uji Biokimia L. glasseri dari ASI $\mathrm{L}_{1}$

\begin{tabular}{|c|c|c|}
\hline No & Jenis Uji & Hasil \\
\hline 1 & D-Galactose & - \\
\hline 2 & D-Cellobiose & + \\
\hline 3 & Saccharose & + \\
\hline 4 & Beta-Galactopyranosidase Indoxyl & - \\
\hline 5 & Maltotriose & + \\
\hline 6 & Phosphatase & + \\
\hline 7 & Leucine Arylamidase & + \\
\hline 8 & Tryosine Arylamidase & + \\
\hline 9 & Arbutin & + \\
\hline 10 & Alpha-Arabinosidase & - \\
\hline 11 & Esculin hydrolysis & + \\
\hline 12 & L-Arabinose & - \\
\hline 13 & ELLMAN & - \\
\hline 14 & Ala-Phe-Pro_Arylamidase & + \\
\hline 15 & $N$-Acetyl-D-Glucosamine & + \\
\hline 16 & $\begin{array}{l}\text { 5-Bromo-4-chloro-3-indoxyl-alpha- } \\
\text { galactoside }\end{array}$ & - \\
\hline 17 & Beta-D-Fucosidase & - \\
\hline 18 & d-Ribose 2 & - \\
\hline 19 & Phenylalanine Arylamidase & + \\
\hline 20 & D-Glukose & + \\
\hline 21 & $\begin{array}{l}\text { 5-Bromo-4-chloro-3-indoxyl-beta- } \\
\text { glucoside }\end{array}$ & + \\
\hline 22 & Beta Mannosidase & - \\
\hline 23 & $\begin{array}{l}\text { 5-Bromo-4-chloro-3-indoxyl-beta- } N \text { - } \\
\text { acetyl-glucosamide }\end{array}$ & - \\
\hline 24 & Phenylphosphonate & - \\
\hline 25 & L-Proline Arylamidase & + \\
\hline 26 & D-Mannose & + \\
\hline 27 & Urease & - \\
\hline 28 & Arginine GP & + \\
\hline 29 & $\begin{array}{l}\text { 5-Bromo-4-chloro-3-indoxyl-alpha- } \\
\text { mannoside }\end{array}$ & - \\
\hline 30 & Alpha-L-Arabinofuranoside & - \\
\hline 31 & L-Pyrrolidonyl-Arylamidase & - \\
\hline 32 & D-Maltose & + \\
\hline 33 & $\begin{array}{l}\text { 5-Bromo-4-chloro-3-indoxyl-beta- } \\
\text { glucuronide }\end{array}$ & - \\
\hline 34 & Pyruvate & - \\
\hline 35 & Alpha-L-Fucosidase & - \\
\hline 36 & D-xylose & - \\
\hline
\end{tabular}

Penggunaan bakteri probiotik untuk kesehatan mempunyai keunggulan karena merupakan pendekatan alami dengan tidak mengganggu mikroflora alami dalam tubuh manusia. Probiotik mampu merangsang fungsi antibodi dalam sistem kekebalan tubuh sehingga mampu meningkatkan daya tahan tubuh. Kultur probiotik dalam usus juga dapat mengurangi bahaya penyerapan bahan kimia yang bersifat karsinogen dengan menetralisirnya, mecegah kerusakan DNA pada sel terten- 
tu, menghasilkan komponen yang menghambat pertumbuhan sel tumor, dan merangsang system kekebalan untuk lebih tahan terhadap pembelahan sel kanker (Surono, 2004).

Kajian mengenai L. glasseri teridentifikasi perlu diuji lebih lanjut mengenai sifat morfologi sel, viabilitas sel, dan karakteristik sel sehingga dapat diperoleh metode yang tepat untuk peremajaan dan aplikasi pada produk pangan.

\section{KESIMPULAN}

1. Hasil penelitian menunjukkan bahwa $L$. glasseri hanya ditemukan $20 \%$ dari sampel ASI wanita menyusui usia $12-60$ hari.

2. Isolate $L$. glasseri terseleksi memiliki ciri morfologi: gram positif, katalase negative, non motil, anaerob, bentuk koloni bulat dengan permukaan cembung, warna koloni putih susu agak krem, tekstur koloni agak keras, koloni tumbuh dibagian tengah media agar (anaerob), sel berbentuk basil dengan ukuran sel 2,0 $\mu \mathrm{m}$.

3. Hasil uji biokimia menunjukkan bahwa isolate $L$. glasseri terseleksi mampu menguraikan: D-Cellobiose, Saccharose, Maltotriose, Phosphatase, Leucine Arylamidase, Tryosine Arylamidase, Arbutin, Esculin hydrolysis, Ala-PhePro_Arylamidase, $N$-Acetyl-DGlucosamine, Phenylalanine Arylamidase, D-Glukose, 5-Bromo-4-chloro-3-indoxylbeta-glucoside, L-Proline Arylamidase, DMannose, Arginine GP, D-Maltose.

\section{UCAPAN TERIMAKASIH}

Ucapan terimakasih dan penghargaan yang tak terhingga disampaikan kepada:

1. Rektor Universitas Padjadjaran atas bantuan dana penelitian yang diberikan selama penelitian melalui program RDPU.

2. Prodi Teknologi Pangan - FTIP UNPAD dan Laboratorium Bakteriologi - Biofarma, atas fasilitas laboratorium yang diberikan untuk kelancaran penelitian.

\section{DAFTAR PUSTAKA}

Baltova, Kalinka and Zhechko Dimitrov. 2014. Probiotic and Cultural Characteristic of Strain Lactobacillus gasseri 4/13 of Human Origin. Biotechnology \& Biotechnological Equipment Vol. 28, No. 6. P: 1084-1088.

Falsen, E, Pascual, C, Sjoden, B, Ohlen, M, \& Collins, MD. (1999) Phenotypic and phylogenetic characterization of a novel Lactobacillus species from human sources: description of Lactobacillus iners sp. Nov. Int J Syst Bacteriol. 49. 217-221.

Hanidah, In-In., dan E. Lembong. 2015. Identifikasi Kandidat Bifidobac-terium bifidum dan Lactobacillus reuteri dari Air Susu Ibu. Jurnal Teknotan vol. 9 No. 3. Hal. 1494-1498.

Hartanti, L. 2005. Pengaruh Rasio dan Konsentrasi Bakteri Lactobacillus bulgaricus, Sterptococcus thermophilus dan Bifidobacterium bifidum Terhadap Karakteristik Yoghurt Probiotik. Skripsi. FTIP. Unpad Jatinangor.

Labeda, P. David. 1990. Isolation of Biotechnological Organisms from Nature. McGraw-Hill Publishing Co. New York.

Martin, R., E. Jimenez, H. Heilig, L. Fernandez, M.L. Marin, E.G. Zeotendal, and J.M. Rodriguez. 2009. Isolation of Bifidobacteria from Breast Milk and Assessment of the Bifidobacterial Population by PCR-Denaturing Gradient Gel Electrophoresis and Quantitative Real-Time PCR. Applied and Environmental Microbiology, p. 965-969.

Olivares, M., M. Diaz-Ropero, N. Gomez, F. Lara-Villoslada, S. Sierra, J.A. Maldonado, R. Martı'n, E. Lopez-Huertas, J.M. Rodriguez, J. Xaus. 2006. Oral Administration of Two Probiotic Strains, Lactobacillus gasseri CECT5714 and Lactobacillus coryniformis CECT5711, Enhances the Intestinal Function of Healthy Adults. Int'1 J. of Food Microbiology 107. P:104-111.

Portinson, Salme. 2013. Clinical effects of Lactobacillus reuteri DSM 17938. Third International Symposium on Probiotics and Prebiotics, Microbiome, Gut-brain Axis in Health and Disease: p35. Jakarta. Sweden.

Roberfroid, M. 2000. Prebiotics and probiotics: are they functional foods. Am J ClinNutr 2000 Jun;71(6 Suppl):1682S-7S.

Sukarminah, Een., Debby M. Sumanti, dan In-In Hanidah. 2016. Mikrobiologi Pangan. Unpad Press. Bandung.

Surono, I.S. 2004. Probiotik Susu Fermentasi dan Kesehatan. Penerbit Tri Cipta Karya, Jakarta. 
Vol. 2, No. 2, Desember 2017: 291-357 AGRICORE-Jurnal Agribisnis dan Sosial Ekonomi Pertanian 